\title{
Complete Ossification of the Superior Transverse Scapular Ligament in a Nigerian Male Adult
}

\author{
Osificación Completa del Ligamento Transverso Escapular \\ Superior en un Hombre Adulto Nigeriano
}

Osuagwu, F. C.; Imosemi, I. O. \& Shokunbi, M. T.

OSUAGWU, F. C.; IMOSEMI, I. O. \& SHOKUNBI, M. T. Complete ossification of the superior transverse scapular ligament in a Nigerian male adult. Int. J. Morphol., 23(2):121-122, 2005.

SUMMARY: Complete ossification of the superior transverse scapular ligament is generally considered to be rare and has not been previously described in a Nigerian. In the diagnosis of suprascapular nerve entrapment syndrome, variations in the anatomy of the superior transverse scapular ligament must be considered as possible etiologic factors, as illustrated by this case report.

KEY WORDS: Superior transverse scapular ligament; Ossification; Entrapment neuropathy.

\section{INTRODUCTION}

The documented variations of the superior transverse scapular ligament include calcification, partial or complete ossification and multiple bands (Ticker et al., 1998).

In the diagnosis of suprascapular nerve entrapment syndrome, these variations in the anatomy of the superior transverse scapular ligament sometimes feature in the hierarchy of possible etiologic factors (Callahan et al.,1991). However, suprascapular nerve entrapment syndrome has also been described in clinical scenarios without a visible ossification of the superior transverse scapular ligament. Complete ossification of the superior transverse scapular ligament or suprascapular nerve entrapment syndrome has not been previously described amongst Nigerians. In this case report, we describe a completely ossified superior transverse scapular ligament in a male adult Nigerian scapular.

\section{CASE REPORT}

During routine bone extraction from a male cadaver for our bone library, we observed that the left superior transverse scapular ligament was completely ossified. The ligament stretched across the entire length of the suprascapular notch of the left scapular.The superior maximal length was $0.5 \mathrm{~cm}$ long, while in inferior maximal length was $0.3 \mathrm{~cm}$ long.
The thickness was $0.3 \mathrm{~cm}$.

The left scapular bone appeared normal in all other parameters, the entire left scapula's dry weight was $73.30 \mathrm{~g}$.

\section{DISCUSSION}

Cohen et al. (1997) described a familial case of calcification of superior transverse scapular ligament affecting a 58 year old man and his son who had calcification of superior transverse scapular ligament causing entrapment neuropathy of the suprascapular nerve and its attendant clinical symptoms of pain, weakness, atrophy of the supraspinatus muscle.

There are descriptions in the literature of bifid (Alon et al., 1998) and trifid (Ticker et al.) superior transverse scapular ligaments, with the former including an account of ensuing suprascapular nerve entrapment.

Rengachary et al. (1979) have in their report of the anatomical variations observed in the suprascapular notch area described six different types. These anatomical variations of the suprascapular notch and the superior transverse scapular ligament constitute potential predisposing factors to suprascapular nerve entrapment. 
Despite this possible relationship between suprascapular nerve entrapment syndrome, possible morphological differences in the infraspinatus or supraspinatus and variations in the superior transverse scapular ligament, we were unable to correlate all the aforementioned in the subject of this case report due to poor documentation (Osuagwu et al., 2004).

The present case report demonstrates that complete ossification of superior transverse scapular ligament can occur in this population and that further studies are required to determine its frequency and significance in Nigerian Africans.

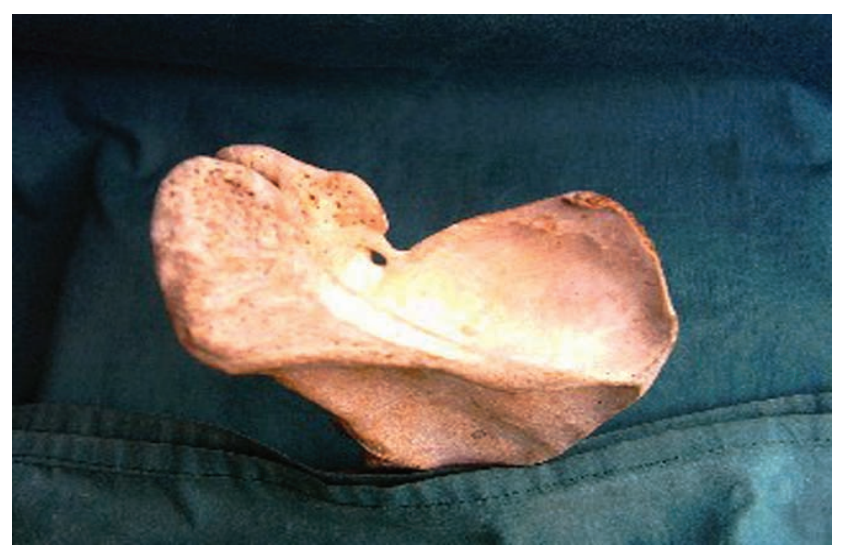

Fig. 1. Superior view of the left scapula.

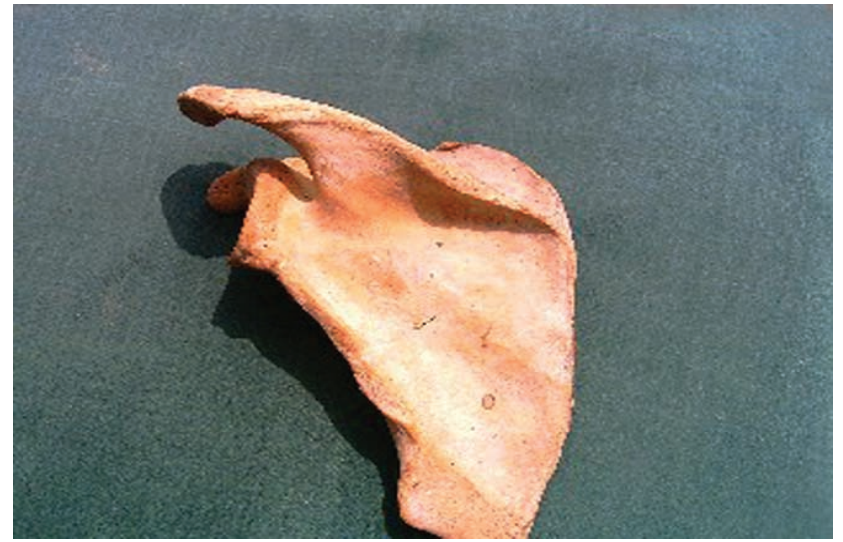

Fig. 2. Dorsal view of the left scapula.

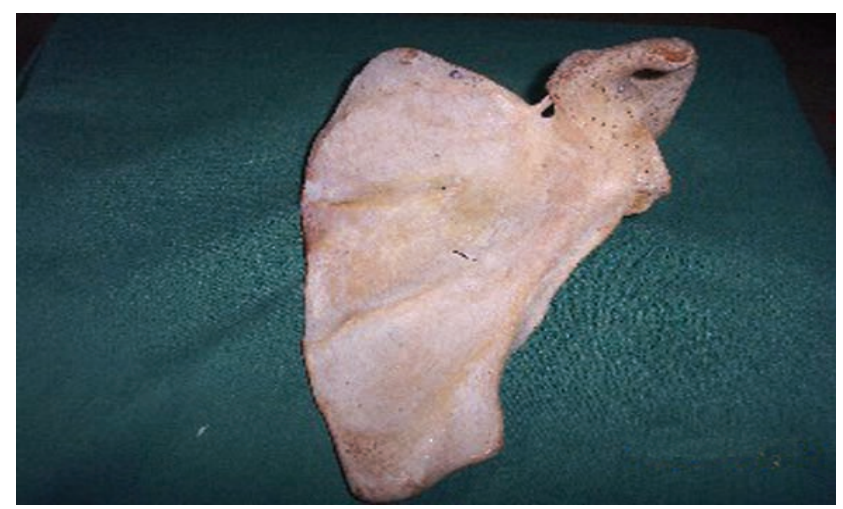

Fig. 3. Ventral view of the left scapula.

OSUAGWU, F. C.; IMOSEMI, I. O. \& SHOKUNBI, M. T. Osificación completa del ligamento transverso escapular superior en un hombre adulto nigeriano. Int. J. Morphol., 23(2):121-122, 2005.

RESUMEN: La osificación completa del ligamento transverso escapular superior es generalmente considerado como raro y no existen datos previamente descritos en nigerianos. En el diagnóstico del síndrome de compresión del nervio supraescapular, variaciones anatómicas del ligamento transverso escapular superior pueden ser consideradas un posible factor etiológico, como es el caso descrito.

PALABRAS CLAVE: Ligamento transverso escapular superior; Osificación; Síndrome de compresión nerviosa.

\section{REFERENCES}

Alon, M.; Weiss, S.; Fischel, B. \& Dekel, S. Bilateral suprascapular nerve entrapment syndrome due to anomalous transverse scapular ligament. Clin. Orthop. , 234:31-3,1988.

Callahan, J. D.; Scully, T. B.; Shapiro, S. A. \& Worth, R. M. Suprascapular nerve entrapment. A series of 27 cases. $J$. Neurosurg., 74:893-6, 1991.

Cohen, S. B.; Dnes, D. M. \& Moorman, C. T. Familial calcification of the superior transverse scapular ligament causing neuropathy. Clin. orthop. Rel. Res., 334:131-5,1997.

Osuagwu, F. C.; Imosemi, I. O. \& Oladejo, O. W. Sources of cadaver used for dissection at the Ibadan Medical School, NigeriaAnalysis of a three year data. African Journal of Biomedical Research., 7:93-5, 2004.
Rengachary, S. S.; Neff, J. P.; Singer, P. A. \& Brackett, C. F. Suprascapular nerve entrapment neuropathy: A clinical, anatomical and comparative study. Part 1: Clinical study. Neurosurgery, 5:441-6,1979.

Ticker, J. B.; Djurasovic, M.; Strauch, R. J.; April, E.W.; Pollock, R. G.; Flatow, E. L. \& Bigliani, L. U.The incidence of ganglion cysts and variations in anatomy along the course of the suprascapular nerve. J. Shoulder Elbow Surg., 7(5):472-8, 1998.

Correspondence to:

Dr. Fernand Osuagwu

Department of Anatomy, College of Medicine

University of Ibadan, Ibadan,

NIGERIA

Email: ferdnand_o@yahoo.com

Received: 12-01-2005

Tel: $+234-8034704294$ (cell) 